\title{
Freshwater sponge-dwelling Chironomidae (Insecta, Diptera) in northeastern Brazil
}

\author{
Ingrid da Silva Fernandes ${ }^{1}$ \\ Gilberto Nicacio ${ }^{1}$ \\ Gilberto Gonçalves Rodrigues ${ }^{1}$ \\ Fabio Laurindo da Silva ${ }^{2,3}$ *

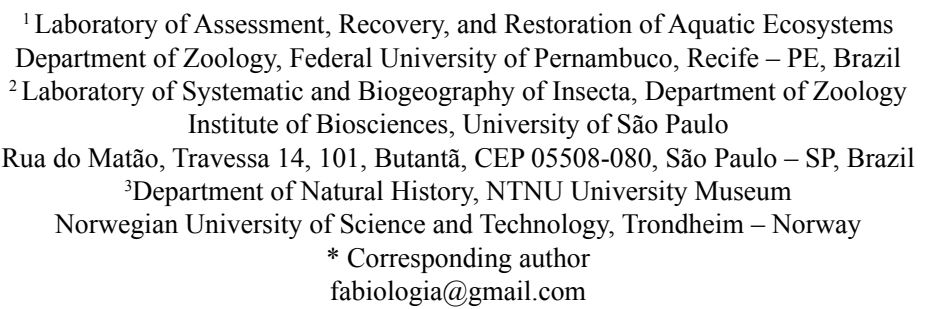

Submetido em 18/07/2018

Aceito para publicação em 19/11/2018

\section{Resumo}

Chironomidae habitantes de esponjas de água doce no nordeste do Brasil. A região Neotropical possui uma rica fauna de esponjas de água doce, porém o conhecimento sobre sua taxonomia, bem como sobre as comunidades dentro delas permanece fragmentado. Larvas de Chironomidae (Insecta, Diptera) associadas a esponjas de água doce têm sido amplamente relatadas na literatura, com alguns gêneros que são reconhecidos como contendo espécies exclusivamente dependentes desses organismos. Neste estudo, analisamos a ocorrência de larvas de Chironomidae associadas a esponjas de água doce (Spongillidae) no nordeste do Brasil. As amostras foram coletadas em dois sistemas aquáticos em Pernambuco, no período de fevereiro de 2011 a outubro de 2012. No Rio Sirinhaém, Corvoheteromeyenia australis (Bonetto \& Ezcurra de Drago) foi a única esponja coletada, sendo que Polypedilum Kieffer, Goeldichironomus Fittkau, Xenochironomus Kieffer e Cricotopus Van der Wulp foram os Chironomidae registrados como representantes dessa fauna associada. Por outro lado, no tanque de piscicultura, Heteromeyenia cristalina Batista, Volkmer-Ribeiro \& Melão, Radiospongilla inesi Nicacio \& Pinheiro e Tubella variabilis Boneto \& Ezcurra de Drago foram as esponjas coletadas, e Polypedilum, Chironomus Meigen, Dicrotendipes Kieffer e Goeldichironomus foram as larvas associadas a essas espécies de esponjas. Embora apenas espécies pertencentes ao gênero Xenochironomus sejam relatadas em estreita interação com esponjas de água doce, aqui documentamos outros gêneros de Chironomidae também associados a esses organismos. No entanto, é necessária uma investigação mais aprofundada para entender melhor como as larvas de Chironomidae usam esponjas como abrigo e/ou prevenção de predação de forma facultativa. O objetivo do presente estudo foi analisar a ocorrência de habitantes de Chironomidae de esponjas de água doce em sistemas aquáticos no estado de Pernambuco, a fim de incrementar o conhecimento de Chironomidae habitantes de esponjas no nordeste do Brasil.

Palavras-chave: Insetos aquáticos; Interação interespecífica; Porifera; Esponjas; Neotropical 


\section{Abstract}

The Neotropical region possesses a rich freshwater sponge fauna; however, knowledge about its taxonomy and the community inside the sponges remains fragmentary. Chironomidae (Insecta, Diptera) larvae associated with freshwater sponges have been largely reported in literature and some genera are recognized as containing species exclusively dependent on these organisms. In this study, we analyze the occurrence of chironomid larvae associated with freshwater sponges (Spongillidae) in northeastern Brazil. Samples were collected in two aquatic systems in Pernambuco, Brazil, in February 2011 and October 2012. In the Rio Sirinhaém, Corvoheteromeyenia australis (Bonetto \& Ezcurra de Drago) was the only sponge collected, and Polypedilum Kieffer, Goeldichironomus Fittkau, Xenochironomus Kieffer and Cricotopus Van der Wulp were the chironomids found as its associated fauna. On the other hand, in the fishpond, Heteromeyenia cristalina Batista, VolkmerRibeiro \& Melão, Radiospongilla inesi Nicacio \& Pinheiro and Tubella variabilis Boneto \& Ezcurra de Drago were the collected sponges, and Polypedilum, Chironomus Meigen, Dicrotendipes Kieffer and Goeldichironomus were the larvae associated with these species. Although only species of Xenochironomus are reported to have close interactions with freshwater sponges, herein we document other Chironomidae genera associated with these organisms. Nevertheless, further investigations are needed to better understand how chironomid larvae use sponges as shelter and/or to avoid predation in a facultative way. The objective of the present study was to analyze the occurrence of Chironomidae inhabitants of freshwater sponges in aquatic systems in the state of Pernambuco, in order to contribute to the knowledge of sponge-dwelling chironomids in northeastern Brazil.

Key words: Aquatic insects; Interspecific interaction; Porifera; Sponges; Neotropical

\section{Introduction}

The non-biting midges Chironomidae (Insecta: Diptera) are true flies and the most widely distributed free-living holometabolous insects (CRANSTON, 1982; FERRINGTON, 2008). Species of Chironomidae inhabit an enormous variety of aquatic ecosystems, ranging from moist soils to pools in tree holes, and from lowoxygen lake sediments to fast-flowing mountain streams (FERRINGTON et al., 2008). For chironomids, the adult life stage is ephemeral and most of the lifespan is spent as a larva (THIENEMANN, 1954; TOKESHI, 1995). The numerous species and habitat diversity make taxa of this family valuable indicator species for lentic and lotic aquatic ecosystems, and particularly appropriate for phylogenetic and biogeographical research (SILVA; EKREM, 2016). While recent years have seen increased activity concerning the study of Chironomidae fauna in the Neotropical region (e.g., OLIVEIRA et al., 2013; TRIVINHO-STRIXINO et al., 2013; 2015; ANDERSEN; PINHO, 2014; SILVA et al., 2014a; 2014b; ANDERSEN et al., 2015; SILVA; WIEDENBRUG, 2015; SIRI et al., 2015; PARISE; PINHO, 2016; SILVA; OLIVEIRA, 2016; SILVA; FARRELL, 2017; SILVA; FERRINGTON, 2018), what is known about the interactions between some species of Chironomidae and their hosts remains fragmentary (TRIVINHO-STRIXINO et al., 2012).

Interactions between organisms, such as competition and predation, have been reported as factors that regulate communities (RICKLEFS, 1987). However, interactions, such as commensalism, have been briefly described and still require further investigation, as indicated by Holomuzki et al. (2010). Freshwater sponges (Spongillidae, Porifera) comprise a group of utmost significance for the metabolism of ecosystems, acting as important aquatic filter-feeding organisms. The association between chironomids and these organisms has been occasionally mentioned in the literature (STEFFAN, 1967; ROBACK, 1968; MATTESON; JACOBI, 1980; TOKESHI, 1993; 1995; MELÃO; ROCHA, 1996; ROQUE et al., 2004; ROQUE; TRIVINHO-STRIXINO, 2005; FUSARI et al., 2012; 2013; 2014). However, in the Neotropics only three genera are recognized as having this type of interaction: Ablabesmyia Johannsen; Xenochironomus Kieffer; and Oukuriella Epler (FUSARI et al., 2012; 2013). Additionally, questions addressing whether larvae of other species of Chironomidae can inhabit freshwater sponges without necessarily having an obligate association are still unclarified. In this study, 
we analyze the occurrence of chironomid inhabitants of freshwater sponges in aquatic systems in the state of Pernambuco, Brazil.

\section{Material and Methods}

\section{Study area}

The Rio Sirinhaém originates in the municipality of Camocim de São Félix, Pernambuco, Brazil, and extends about $158 \mathrm{~km}$ in a northwest-southeast direction. It also crosses the municipalities of Gameleira and Cortes, where part of this study was conducted $\left(08^{\circ} 30^{\prime} \mathrm{S}\right.$, $\left.35^{\circ} 31^{\prime} \mathrm{W}\right)$. The second sampling site was in a fishpond located on the campus of the Federal Rural University of Pernambuco ( $\left.8^{\circ} 01^{\prime} \mathrm{S}, 34^{\circ} 56^{\prime} \mathrm{W}\right)$. This system presents different types of sediments (sand and clay) at the bottom and is formed by water flowing from Plata Creek, located in Parque Dois Irmãos, in northwestern Recife, which had its course changed to supply the fishpond to farm tilapia for scientific research.

\section{Collection and identification}

Collections were made in February 2011 in Rio Sirinhaém and in October 2012 in the fishpond. In each of these environments, we searched for sponges on several potential substrates, such as decaying wood, rocks, and macrophytes. All samples were field-preserved using $70 \%$ ethanol. In the laboratory, the sponges were dissected and slide-mounted following the procedures described in Hajdu et al. (2011). Identifications were made by the team of the Laboratory of Porifera, Federal University of Pernambuco, based on Manconi and Pronzato (2002) and Nicacio and Pinheiro (2015), mainly using sponge spicules. Larval chironomids associated with different sponges were sorted using a stereomicroscope and slide-mounted following the procedure outlined by Pinder (1983). The material was morphologically identified to the lowest taxonomic level possible based on the keys in Wiederholm (1983), Epler (2001), Andersen et al. (2013), Trivinho-Strixino
(2014) and Silva et al. (2018), and occasionally original descriptions. Gut content examination was made according to Mcshaffrey and Olive (1985), based on previously prepared slides of larvae. No attempt was made during collection to prevent regurgitation of food in the gut; although, all analyzed larvae had some gut content. Guts were left in the bodies and examined microscopically by transparency through the cuticle (for more details see SILVA et al., 2008a; 2008b). Voucher specimens are deposited in the Laboratory of Assessment, Recovery, and Restoration of Aquatic Ecosystems, at the Federal University of Pernambuco.

\section{Results}

In total, 266 representatives of subfamilies Chironominae and Orthocladiinae were recorded inhabiting four species of freshwater sponges (Table 1). Six genera were identified. Polypedilum Kieffer and Goeldichironomus Fittkau were the most abundant genera, predominating in all samples. Xenochironomus was only sampled in the Rio Sirinhaém, while Chironomus Meigen and Dicrotendipes Kieffer occurred entirely in the fishpond. Only one genus was recorded for Orthocladiinae, Cricotopus Van der Wulp. In the Rio Sirinhaém the chironomid fauna were exclusively associated with Corvoheteromeyenia australis (Bonetto; Ezcurra de Drago). Other species of freshwater sponges were not found in this environment. On the other hand, in the fishpond, Chironomidae larvae were collected in association with Heteromeyenia cristalina Batista, Volkmer-Ribeiro \& Melão, Radiospongilla inesi Nicacio \& Pinheiro and Tubella variabilis Bonetto \& Ezcurra de Drago. This aquatic ecosystem presented not only the highest diversity of freshwater sponges, but also the highest abundance of chironomids (Table 1). In general, the gut content of the analyzed larvae was predominantly diatoms and fine organic matter. Spicules of $H$. crystalina were found in larvae of Goeldichironomus, while spicules of $C$. australis were observed in larval Cricotopus. 
TABLE 1: Absolute (N) and relative (\%) abundance of chironomid larvae in freshwater sponges in the Rio Sirinhaém and the fishpond, Pernambuco, Brazil. Corvoheteromeyenia australis (A), Heteromeyenia cristalina (B), Radiospongilla inesi (C) and Tubella variabilis (D).

\begin{tabular}{l|lcccccc}
\hline \multicolumn{2}{c}{ Diptera: Chironomidae } & \multicolumn{2}{c}{ Rio Sirinhaém } & Sponge & \multicolumn{2}{c}{ Fishpond } & Sponge \\
\hline \multicolumn{1}{c}{ Subfamily } & \multicolumn{1}{c}{ Taxa } & N & $\mathbf{\%}$ & & N & \% & \\
\hline \multirow{5}{*}{ Chironominae } & Polypedilum (Asheum) sp. & 20 & 30.3 & A & 25 & 12.5 & A-C \\
& Chironomus sp. & 0 & 0.0 & - & 15 & 7.5 & A-D \\
& Dicrotendipes sp. & 0 & 0.0 & - & 17 & 8.5 & B-C \\
& Goeldichironomus neopictus & 17 & 25.8 & A & 143 & 71.5 & A-C \\
& Xenochironomus sp. & 14 & 21.2 & A & 0 & 0.0 & A \\
\hline Orthocladiinae & Cricotopus sp. & 15 & 22.7 & A & 0 & 0.0 & A \\
\hline \multicolumn{1}{l}{ Total } & $\mathbf{6 6}$ & $\mathbf{1 0 0}$ & & $\mathbf{2 0 0}$ & $\mathbf{1 0 0}$ & \\
\hline
\end{tabular}

\section{Chironomus Meigen, 1800}

Chironomus is a cosmopolitan genus with several hundred species. Numerous species of this group are very abundant in heavily polluted standing or running waters, whereas some species usually colonize small water bodies, such as fish breeding tanks, where they complete their life cycle in a few days (CORREIA et al., 2013). Spies and Reiss (1996) catalogued 19 species from the Neotropical region. However, this number clearly represents outdated knowledge and significantly underestimates the real diversity of Chironomus in the Neotropics, considering that several new species have been described more recently (CORREIA; TRIVINHOSTRIXINO 2005; 2007; CORREIA et al., 2005; 2006; 2013). In our study, larvae of Chironomus (see Figure 1a) were found associated with the following freshwater sponges: Corvoheteromeyenia australis (Bonetto; Ezcurra de Drago), Heteromeyenia cristalina Batista, Volkmer-Ribeiro \& Melão, Radiospongilla inesi Nicacio $\&$ Pinheiro and Tubella variabilis Boneto \& Ezcurra de Drago. None of the larvae analyzed in the present study had any spicules in their digestive tracts, which were filled with debris, sand and diatoms.

\section{Cricotopus Van der Wulp, 1874}

This genus is one of the largest in subfamily Orthocladiinae, comprising five subgenera, and has a worldwide distribution (CRANSTON et al., 1989; ASHE; O'CONNOR, 2009). Larval Cricotopus are known to inhabit a wide range of water bodies, from pristine streams and brooks to eutrophic ponds and brackish estuaries (HIRVENOJA, 1973; BOESEL, 1983). Certain species may become so abundant in eutrophic waters that adult swarms become a nuisance (SPIES, 2000; HIRABAYASHI et al., 2004). The group is often recorded in association with aquatic macrophytes, algae and sometimes cyanobacteria. Some larvae mine in macrophytes, while many graze on the surfaces (CRANSTON et al., 1983), and according to Roback (1968) they are capable of living in and on sponges as well as other habitats. In our study, larvae of Cricotopus (Figures 1b;1c) were associated with Corvoheteromeyenia australis. The digestive tract was filled with debris and spicules of the aforementioned freshwater sponge (Figure 1d).

\section{Dicrotendipes Kieffer, 1913}

Dicrotendipes is a large group with a worldwide distribution. It is commonly found in littoral sediments of brackish and fresh water, in lotic and lentic conditions, in pristine or degraded habitats (EPLER, 2001), and in many cases it is the most abundant organism. Although larvae occur in sediments, they are most often encountered on vegetation (EPLER, 2001). The group is considered pollution-sensitive to most forms of toxic pollution but thrives in areas containing high levels of nutrients or organic wastes (SIMPSON; BODE, 1980). Its most common associates in such situations are oligochaetes. In our study, larval Dicrotendipes were found in association with Heteromeyenia cristalina and 
Radiospongilla inesi (Figure 1e). None of the larvae analyzed in the present study had any spicules in their digestive tracts. This might be due to the fact that the larvae here examined may not have achieved their full body growth, since it seems that the presence of spicules in the gut of sponge-dwelling chironomid mainly occurs in final instars (ROBACK, 1968).

\section{Goeldichironomus Fittkau, 1965}

Goeldichironomus is a Pan-American genus, which commonly occurs in eutrophic standing and slowmoving water, where it is found in or on sediments and aquatic plants (EPLER, 2001). Immatures of this genus favor floating and drifting vegetation of small standing water bodies. Several species are miners that form small tunnels in the petioles of macrophytes and decaying wood (REISS, 1974; TRIVINHO-STRIXINO, 2014). They also live in burrows in plant material made by other organisms (EPLER, 2001). The larvae analyzed in our study were identified as Goeldichironomus neopictus Trivinho-Strixino and Strixino (Figure 1f). These were the most common larvae and were encountered in association with Corvoheteromeyenia australis, Heteromeyenia cristalina and Radiospongilla inesi. Larval Goeldichironomus were found throughout the body of the sponge. The digestive tract contained many sponge spicules of $H$. cristalina (Figures 1g; 1h), indicating that the larva was probably feeding on this sponge and its presence may not have been merely accidental.

\section{Polypedilum Kieffer, 1912}

This genus is one of the largest in the Chironominae and has eight subgenera, a worldwide distribution, and about 440 described species (SÆTHER et al., 2010). Larvae of Polypedilum occur in nearly all types of still and flowing waters, ranging from pristine to heavily degraded, except for in the arctic and high mountains. Sediments are the preferred substratum. Some species are also found on hard substrata, as well as mining aquatic plants and in bromeliad tanks (CRANSTON; EPLER, 2013). Larval Polypedilum are filter-feeders, and their occurrence seems to be governed more by current speed and the amount of suspended food particles than by water quality (SIMPSON; BODE, 1980). The immatures analyzed in our study were identified as Polypedilum (Asheum) sp. Sublette (Figures 1i; 1j), which is commonly found in lakes, reservoirs and rivers, mainly in association with aquatic macrophytes (TRIVINHO-STRIXINO, 2014). The taxon was previously recorded for southeastern Brazil by Silva and Farrell (2017). Herein, the species was found interacting with Corvoheteromeyenia australis, Heteromeyenia cristalina and Radiospongilla inesi. None of the larvae examined had any spicules in their digestive tracts, which were basically filled with debris.

\section{Xenochironomus Kieffer, 1912}

This is a small genus with species distributed in the Afrotropical, Nearctic and Neotropical regions. Larvae of Xenochironomus are obligate miners in freshwater sponges in both standing and flowing waters (CRANSTON; EPLER, 2013). The immatures of Xenochironomus can be found in freshwater sponges with the exception of Xenochironomus canterburyensis (FREEMAN, 1959), which has been reported in association with Mollusca (FORSYTH; MCCALLUM, 1978). This is the first record of Xenochironomus from the Northeast Region of Brazil. The larvae have very large salivary glands and line the tubes they create with silk as they move along (ROBACK, 1968). The immatures analyzed here were identified as Xenochironomus (Figures $1 \mathrm{k} ; 11$ ) and were found associated only with Corvoheteromeyenia australis. Some were in gently curved tubes, both ends of which opened on the surface of the sponge, and others were in the internal cavities of the sponge. None of the larvae found in the present study had any spicules in their digestive tracts. 
FIGURE 1: Freshwater sponge-dwelling Chironomidae (Insecta, Diptera) in northeastern Brazil.
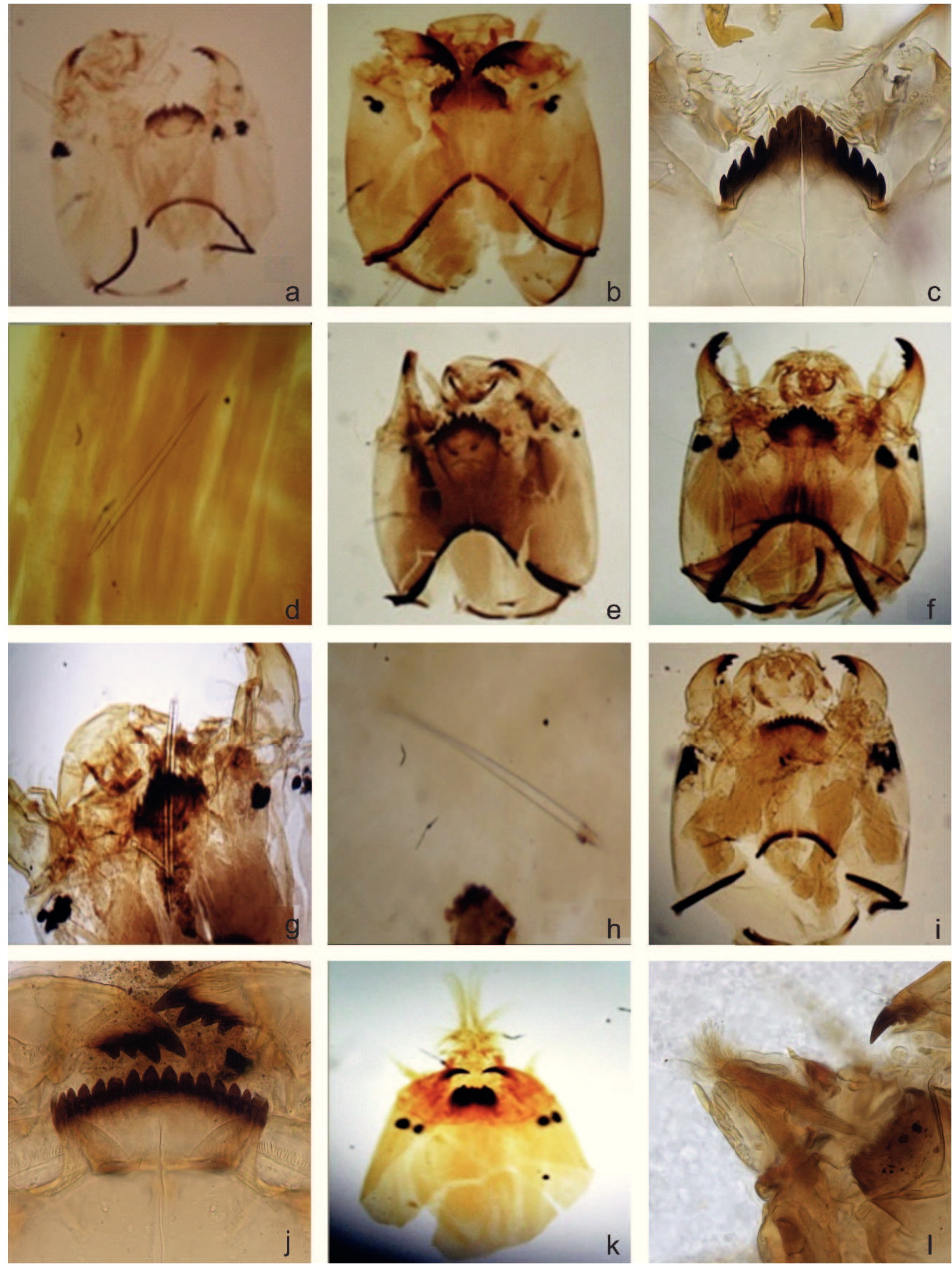

Legend: a) Chironomus Meigen. b-c) Cricotopus Van der Wulp. d) sponge spicules of Corvoheteromeyenia australis (Bonetto \& Ezcurra Drago) in Cricotopus Van der Wulp. e) Dicrotendipes Kieffer. f) Goeldichironomus Fittkau. g-h) sponge spicules of Heteromeyenia crystalline Baptist, Melon \& Volkmer-Ribeiro in Goeldichironomus Fittkau. i-j) Polypedilum Kieffer. k-I) Xenochironomus Kieffer. 


\section{Discussion}

Spongillidae has an interspecific relationship with the family Chironomidae. In our study, we record for the first time the larvae of Polypedilum, Chironomus, Cricotopus, Dicrotendipes and Goeldichironomus associated with freshwater sponges. To most insects, such as baetid and heptageniid mayfly nymphs, hydropsychid caddisfly larvae, as well as larval chironomids, the sponges seem to be merely another substrate (ROBACK, 1968), since there was no evidence indicating an obligate association of chironomids with the sponges, despite the fact that larvae were found living within the sponges and/or feeding on them. However, the association between chironomid larvae and freshwater sponges might benefit the chironomids by improving feeding opportunity, providing protection from disturbances and decreasing predation risks. This appears to be the scenario in the fishpond, where the association of larval chironomids with sponges may be related to a defensive strategy and/or predation avoidance (mainly from tilapia), since these taxa were not found free-living or on the bottom and walls of this environment. Moreover, the higher diversity of sponges in the fishpond suggests that this environment provides more adequate conditions for the development of these organisms, which may be related to the lentic character of the system compared to the Rio Sirinhaém with lotic characteristics and lower diversity.

Despite the presence of spicules in the gut content of some examined larvae, this association might be considered facultative, since except for Xenochironomus, all the other genera are widely recorded in different environments. Furthermore, the amount of spicules observed does not seem to be enough to assure this association as an obligate relationship, since spicules were found associated with other types of food, such as detritus and diatoms, which are commonly recorded in the Chironomidae diet. Roque and Trivinho-Strixino (2005) described Xenochironomus ceciliae as a freshwater spongedwelling Chironomidae in the upper Paraná River. We recorded larvae of Xenochironomus in association with C. australis. Moreover, the water quality of the Rio
Sirinhaém, which is rich in fine particles of organic matter, seems to be suitable for the development of the sponge and the observed interspecific interaction with chironomids. Larvae of Xenochironomus have a brush of numerous long labral setae, which indicates a filter-feeding habit, likely related to the particles originating from the aquifer system of sponges (ROQUE; TRIVINHO-STRIXINO, 2005).

When comparing our results with Roback (1968) and Fusari et al. (2008), who recorded several larvae of Chironomidae associated with different species of freshwater sponges, it is possible that some species of the following genera might still be found interacting with sponges: Oukuriella Epler, Orthocladius Van der Wulp and Stenochironomus Kieffer. Even though our inventory documents 266 representatives of two subfamilies living in four species of freshwater sponges, we consider this a small freshwater spongedwelling chironomid community for northeastern Brazil. We believe that collections in different periods and broadening the variety of sampling habitats and geographic area may reveal a greater diversity than currently recorded. Despite the increased activity in studying the Neotropical chironomid fauna in recent years, data on the interaction between chironomids and freshwater sponges remain fragmentary. Thus, additional inventories are needed to improve our understanding of the insects that might be associated and to add to the information about those already known to be associated. Studies on interspecific interactions between chironomids and sponges remain incipient and, due to a lack of information, the relevance of obligatory or optional associations for Spongillidae and Chironomidae larvae is still unclarified. This study reports for the first time the larvae of Polypedilum, Chironomus, Dicrotendipes and Goeldichironomus living inside freshwater sponges. Despite that the association between these organisms might benefit the chironomids by improving feeding opportunity and providing protection, no evidence indicates an obligate relationship between these taxa and the different species of freshwater sponges recorded. 


\section{Acknowledgement}

We thank Ulisses Pinheiro (Federal University of Pernambuco) for the valuable suggestions about this manuscript. F. L. da Silva was supported by fellowships from the Coordination for the Improvement of Higher Education Personnel (CAPES - 2014/9239-13-8) and São Paulo Research Foundation (FAPESP - 2016/070398 and 2018/01507-5).

\section{References}

ANDERSEN, T.; CRANSTON, P. S.; EPLER, J. H. Chironomidae of the Holarctic region: keys and diagnoses. Part 1. Larvae. Insect Systematics \& Evolution, Stuttgart, v. 66, p. 1-573, 2013.

ANDERSEN, T.; MENDES, H. F.; PINHO, L. C. Mariambera, a new genus of Orthocladiinae from Brazil (Insecta: Diptera, Chironomidae). Studies on Neotropical Fauna and Environment, Abingdon, v. 50, p. 24-30, 2015.

ANDERSEN, T.; PINHO, L. C. A new species of Saetherocryptus Andersen et Mendes, 2007 (Diptera: Chironomidae, Orthocladiinae) from the Amazon rainforest, Brazil. Norwegian Journal of Entomology, Oslo, v. 61, p. 160-164, 2014.

ASHE, P.; O'CONNOR, J. P. A world catalogue of Chironomidae (Diptera). Part 1. Buchonomyiinae, Chilenomyiinae, Podonominae, Aphroteniinae, Tanypodinae, Usambaromyiinae, Diamesinae, Prodiamesinae and Telmatogetoninae. Dublin: Irish Biogeographical Society \& National Museum of Ireland, 2009. 445 p.

BOESEL, M. W. A review of the genus Cricotopus in Ohio, with a key to adults of the species of the Northeastern United States (Diptera, Chironomidae). Ohio Journal of Science, Columbus, v. 83, n. 3, p. 74-90, 1983.

CORREIA, L. C. S.; TRIVINHO-STRIXINO, S. New records of Chironomus Meigen, 1803 (Chironomidae, Diptera) in the State of São Paulo (Brazil). Revista Brasileira de Entomologia, Curitiba, v. 49, p. 430-433, 2005.

CORREIA, L. C. S.; TRIVINHO-STRIXINO, S. New species of Chironomus Meigen (Diptera: Chironomidae: Chironominae) from Brazil. Zootaxa, Auckland, v. 1504, p. 53-68, 2007.

CORREIA, L. C. S.; TRIVINHO-STRIXINO, S.; MICHAILOVA, P. A new species of Chironomus Meigen, 1803 (Diptera, Chironomidae) from the southeast of Brazil. Studies on Neotropical Fauna and Environment, Abingdon, v. 40, p. 29-38, 2005.

CORREIA, L. C. S.; TRIVINHO-STRIXINO, S; MICHAILOVA, P. A new species of Chironomus Meigen (Diptera: Chironomidae: Chironominae) from polluted streams of the southeastern Brazil Zootaxa, Auckland, v. 1130, p. 57-68, 2006.

CORREIA, L. C. S., TRIVINHO-STRIXINO, S.; MICHAILOVA, P. Chironomus amissum sp. n. (Diptera, Chironomidae) from southeastern Brazil. Biota Neotropica, Campinas, v. 13, p. 133138, 2013.

CRANSTON, P. S. A key to the larvae of the British Orthocladiinae (Chironomidae). Ambleside: Freshwater Biological Association, 1982. 152 p.
CRANSTON, P. S.; EPLER, J. H. The larvae of Tanypodinae (Diptera: Chironomidae) of the Holarctic region - Keys and diagnoses. Insect Systematics \& Evolution, Stuttgart, v. 66, p. 39136, 2013.

CRANSTON, P. S., OLIVER, D. R.; SÆTHER, O. A. Keys and diagnoses of the larvae of the subfamily Orthocladiinae (Diptera, Chironomidae) of the Holarctic Region. Scandinavian Entomology Supplement, Lund, v. 19, 149-291, 1983.

CRANSTON, P. S.; OLIVER, D. R.; SÆTHER, O. A. Keys and diagnoses of the adult males of the subfamily Orthocladiinae (Diptera, Chironomidae). Scandinavian Entomology Supplement, Lund, v. 34, p. 165-352, 1989.

EPLER, J. H. Identification manual for the larval Chironomidae (Diptera) of North and South Carolina: a guide to the taxonomy of the midges of the southeastern United States, including Florida, North Carolina. Palatka: Department of Environment and Natural Resources and St. Johns River Water Management District, 2001. $526 \mathrm{p}$.

FERRINGTON, L. C. JR. Global diversity of non-biting midges (Chironomidae, Insecta-Diptera) in freshwater. Hydrobiologia, Brussels, v. 595, p. 447-455, 2008.

FERRINGTON, L. C. JR.; BERG, M. B.; COFFMAN, W. P. Chironomidae. In: MERRITT, R. W.; CUMMINS, K. W.; BERG, M. B. (Ed.). An introduction to the aquatic insects of North America. Dubuque: Kendall/Hunt Publishing Co., 2008. p. $847-$ 989.

FORSYTH, D. J.; MCCALLUM, I. D. Xenochironomus canterburyensis (Diptera: Chironomidae), a commensal of Hyridella menziesi (Lamellibranchia) in Lake Taupo; features of pre-adult life history. New Zealand Journal of Zoology, Abingdon, v. 5, p. 795-800, 1978.

FREEMAN, P. A study of the New Zealand Chironomidae (Diptera: Nematocera). Bulletin of the British Museum of Natural History (Zoology), London, v. 7, p. 393-437, 1959.

FUSARI, L. M.; BELLODI, C. S.; LAMAS, C. J. E. A new species of sponge-dwelling Oukuriella (Chironomidae) from Brazil. Zootaxa, Auckland, v. 3764, n. 4, p. 418-426, 2014.

FUSARI, L. M.; OLIVEIRA, C. S. N.; HAMADA, N.; ROQUE, F. O. New species of Ablabesmyia Johannsen from the Neotropical region: first report of a sponge-dwelling Tanypodinae. Zootaxa, Auckland, v.3239, p. 43-50, 2012.

FUSARI, L. M.; ROQUE, F. O.; HAMADA, N. Sponge-dwelling Chironomids in the upper Paraná River (Brazil): Little known but potentially threatened species. Neotropical Entomology, Piracicaba, v. 37, p. 522-527, 2008.

FUSARI, L. M., ROQUE, F. O.; HAMADA, N. Review of Xenochironomus Kieffer, 1921 (Diptera: Chironomidae) with description of six new species. Zootaxa, Auckland, v. 3646, n. 2, p. 101-126, 2013

HAJDU, E.; PEIXINHO, S.; FERNADEZ, J. Esponjas marinhas da Bahia: guia de campo e laboratório. Rio de Janeiro: Sermograf, 2011. $276 \mathrm{p}$.

HIRABAYASHI, K.; MATSUZAWA, M.; YAMAMOTO, M.; NAKAMOTO, N. Chironomid fauna (Diptera, Chironomidae) in a filtration plant in Japan. Journal of the American Mosquito Control Association, Mount Laurel, v. 20, n. 1, p. 74-82, 2004. 
HIRVENOJA, M. Revision der Gattung Cricotopus van der Wulp und ihrer Verwandten (Diptera, Chironomidae). Annales Zoologici Fennici, Helsinki, v. 10, p. 1-363, 1973.

HOLOMUZKI, J. R.; FEMINELLA, J. W.; POWER, M .E. Biotic interactions in freshwater benthic habitats. Journal of the North American Benthological Society, Schaumburg, v. 29, p. 220-244, 2010.

MANCONI, R.; PRONZATO, R. Sub-order Spongillina subord. nov.: freshwater sponges. In: HOOPER, J. N. A.; VAN SOEST, R. W. M. (Ed.). Systema Porifera: a guide to the classification of sponges. New York: Kluwer Academic/Plenum Publ., 2002. p. 9211019.

MATTESON, J. D.; JACOBI, G. Z. Benthic macroinvertebrates found on the freshwater sponge Spongilla lacustris. Great Lakes Entomologist, Valparaiso, v. 13, p. 169-172, 1980.

MCSHAFFREY, D.; OLIVE, J. H. Ecology and distribution of chironomid larvae from Carroll County, Ohio (Diptera: Chironomidae). Ohio Journal of Science, Columbus, v. 85, n. 4, p. 190-198, 1985.

MELÃO, M. G. G.; ROCHA, O. Macrofauna associada a Metania spinata (Carter, 1881), Porifera, Metaniidae. Acta Limnologica Brasiliensia, Rio Claro, v. 8, p. 59-64, 1996.

NICACIO, G.; PINHEIRO, U. Biodiversity of freshwater sponges (Porifera: Spongillina) from northeast Brazil: new species and notes on systematics. Zootaxa, v. 3981, n. 2, p. 220-240, 2015.

OLIVEIRA, C. S. N.; SILVA, F. L.; TRIVINHO-STRIXINO, S. Thalassomyia gutae sp. n., a new marine chironomid (Chironomidae: Telmatogetoninae) from the Brazilian coast. Zootaxa, Auckland, v. 3701, p. 589-95, 2013.

PARISE, A. G.; PINHO, L. C. A new species of Stenochironomus Kieffer, 1919 from the Atlantic Rainforest in southern Brazil (Diptera: Chironomidae). Aquatic Insects, Abingdon, v. 37, p. 1-7, 2016.

PINDER, L. C. V. Introduction - Chironomidae of the Holarctic region. Keys and diagnoses. Larvae. Scandinavian Entomology Supplement, Lund, v. 19, p. 7-10, 1983.

REISS, F. Vier neue Chironomus-Arten (Chironomidae, Diptera) und irhe ökologische Bedeutung für die Benthosfauna zentralamazonischer Seen und Überschwemmungswälder. Amazoniana, Plön, v. 5, p. 3-23, 1974.

RICKLEFS, R. E. Community diversity: relative roles of local and regional processes. Science, New York, v. 235, p. 167-171, 1987.

ROBACK, S. S. Insects associated with the sponge Spongilla fragilis in the Savannah River. Notulae Naturae of the Academy of Natural Sciences of Philadelphia, Philadelphia, v. 412, p. 1-10, 1968.

ROQUE, F. O.; TRIVINHO-STRIXINO, S. Xenochironomus ceciliae (Diptera: Chironomidae), a new chironomid species inhabiting freshwater sponges in Brazil. Hydrobiologia, Brussels, v. 534, p. 231-238, 2005.

ROQUE, F. O.; TRIVINHO-STRIXINO, S.; COUCEIRO, S. R. M.; HAMADA, N.; VOLKMER-RIBEIRO, C.; MESSIAS, M. C. Species of Oukuriella Epler (Diptera, Chironomidae) inside freshwater sponges in Brazil. Revista Brasileira de Entomologia, Curitiba, v. 48, p. 291-292, 2004.
SÆTHER, O. A.; ANDERSEN, T.; PINHO L. C.; MENDES, H. F. The problems with Polypedilum Kieffer (Diptera: Chironomidae), with the description of Probolum subgen. n. Zootaxa, Auckland, v. 2497, p. 1-36, 2010.

SILVA, F. L.; EKREM, T. Phylogenetic relationships of non-biting midges in the subfamily Tanypodinae (Diptera: Chironomidae) inferred from morphology. Systematic Entomology, New York, v. 41, p. 73-92, 2016.

SILVA, F. L.; FARRELL, B. D. Non-biting midges (Diptera: Chironomidae) research in South America: subsidizing biogeographic hypotheses. Annales de Limnologie - International Journal of Limnology, Santa Fé, v. 52, p. 111-128, 2017.

SILVA, F. L.; FERRINGTON, L. C. JR. Systematics of the new world genus Pentaneura Phillipi (Diptera: Chironomidae: Tanypodinae): historical review, new species and phylogeny. Zoologischer Anzeiger, Berlin, v. 271, p. 1-31, 2018.

SILVA, F. L.; MOREIRA, D. C.; BOCHINI, G. L.; RUIZ, S. S. Hábitos alimentares de larvas de Chironomidae (Insecta: Diptera) do Córrego Vargem Limpa, Bauru, SP, Brasil. Biotemas, Florianópolis, v. 21, p. 155-159, 2008a.

SILVA, F. L.; OLIVEIRA, C. S. N. Tanypus urszulae, a new Tanypodinae (Diptera: Chironomidae) from the Neotropical Region. Zootaxa, Auckland, v. 4178, p. 593-600, 2016.

SILVA, F. L.; OLIVEIRA, C. S. N.; TRIVINHO-STRIXINO, S. Metapelopia corbii gen. n., sp. n., a new Tanypodinae (Diptera: Chironomidae) from the Neotropical Region. Annales de Limnologie - International Journal of Limnology, Santa Fé, v. 50, p. 85-95, 2014a.

SILVA, F.L., PINHO, L.C., WIEDENBRUG, S., DANTAS P.S.G., SIRI, A. ANDERSEN, T.; TRIVINHO-STRIXINO, S. Family Chironomidae. In: Hamada, N.; Thorp, J.H.; Rogers, D.C. (Ed.). Thorp and Covich's Freshwater Invertebrates. San Diego: Academic Press, 2018. p. 661-700.

SILVA, F. L.; RUIZ, S. S.; BOCHINI, G. L.; MOREIRA, D. C. Functional feeding habits of Chironomidae larvae (Insecta, Diptera) in a lotic system from Midwestern region of São Paulo State, Brazil. Pan-American Journal of Aquatic Sciences, Rio Grande, v. 3, p. 135-141, 2008b.

SILVA, F. L.; WIEDENBRUG, S. Amazonimyia gigantae gen. n., sp. n., a new Tanypodinae (Diptera: Chironomidae) from the Neotropical Region. Zootaxa, Auckland, v. 3947, p. 275-281, 2015.

SILVA, F. L.; WIEDENBRUG, S.; OLIVEIRA, C. S. N. Denopelopia moema, a new Tanypodinae (Diptera: Chironomidae) from the Neotropical Region, Zootaxa, Auckland, v. 3753, p. $297-$ 299, 2014b.

SIMPSON, K. W.; BODE, R. W. Common larvae of Chironomidae (Diptera) from New York State streams and rivers with particular reference to the fauna of artificial substrates. Bulletin of New York State Museum and Science Service, New York, v. 439, p. 1-105, 1980.

SIRI, A.; CAMPOS, R. E.; DONATO, M. A new species of Larsia Fittkau, 1962 (Diptera: Chironomidae: Tanypodinae) from phytotelmata of Aechmea distichantha Lemaire, 1853 (Bromeliaceae) in Argentina, Aquatic Insects, Abingdon, v. 36, n. 2, p. 125-134, 2015.

SPIES, M. Non-biting 'nuisance' midges (Diptera, Chironomidae) in urban southern California, with notes on taxonomy, ecology 
and zoogeography. In: HOFFRICHTER, O. (Ed.). Late $\mathbf{2 0}^{\text {th }}$ century research on Chironomidae: an anthology from the 13th International Symposium on Chironomidae. Aachen: Shaker Verlag, 2000 p. 621-628.

SPIES, M.; REISS, F. Catalog and bibliography of Neotropical and Mexican Chironomidae (Insecta, Diptera). Spixiana Supplement, Munich, v. 22, p. 61-119, 1996.

STEFFAN, A. W. Ectosymbiosis in aquatic insects. In: HENRY, M. S. (Ed.). Symbiosis. London and New York: Academic Press, 1967, p. 207-290.

THIENEMANN, A. Chironomus: leben, verbreitung und wirtschaftliche bedeutung der chironomiden. Stuttgart: Die Binnengewässer, 1954. 834 p.

TOKESHI, M. On the evolution of commensalism in the Chironomidae. Freshwater Biology, London, v. 29, p. 481-489, 1993.

TOKESHI, M. Life cycles and population dynamics. In: ARMITAGE, P. D.; CRANSTON, P. S.; PINDER, L. C. V. (Ed.). The Chironomidae. Biology and ecology of non-biting midges. London and New York: Chapman and Hall, 1995. p. 225-268.
TRIVINHO-STRIXINO, S. Ordem Diptera. Família Chironomidae. Guia de identificaçāo de larvas. In: HAMADA, N.; NESSIMIAN, J. L.; QUERINO, R. B. (Ed.). Insetos aquáticos na Amazônia Bbrasileira: taxonomia, biologia e ecologia. Manaus: Editora do Instituto Nacional de Pesquisas da Amazônia, 2014. p. 457-660.

TRIVINHO-STRIXINO, S.; SILVA, F. L.; OLIVEIRA, C. S. N. Tapajos cristinae n. gen., n. sp. (Diptera: Chironomidae: Chironominae) from the Neotropical Region. Zootaxa, Auckland, v. 3710, p. 395-399, 2013.

TRIVINHO-STRIXINO, S., SILVA, F. L.; VALENTE-NETO, F. First record of larvae of Chironomidae (Insecta, Diptera) as prey of Temnocephala sp. (Platyhelminthes, Temnocephalidae), an ectosymbiont on larvae of Corydalidae (Megaloptera). Revista Brasileira de Entomologia, Curitiba, v. 56, n. 3, p. 387-389, 2012. TRIVINHO-STRIXINO, S.; WIEDENBRUG, S.; SILVA, F. L. New species of Tanytarsus van der Wulp (Diptera: Chironomidae: Tanytarsini) from Brazil. European Journal of Environmental Sciences, Prague, v. 5, p. 92-100, 2015.

WIEDERHOLM, T. Chironomidae of the Holarctic region. Part. 1: Larvae. Scandinavian Entomology Supplement, Lund, v. 19, p. $1-457,1983$. 